\title{
A Study of Iranian EFL Learners' Understanding and Production of Politeness in Three Speech Acts: Request, Refusal, and Apology
}

\author{
Davud Kuhi \\ Islamic Azad University Maragheh Branch, Maragheh, Iran \\ Email: davudkuhi@yahoo.com \\ Mohammad Jadidi \\ Islamic Azad University Maragheh Branch, Maragheh, Iran \\ Email: jadidimohammad@gmail.com
}

\begin{abstract}
To achieve one of the major objectives of modern foreign language teaching - enabling learners to communicate functionally in the target language - we usually need an ongoing evaluation of our learners' familiarity with different types of speech acts. Based on such an assumption, this study attempted to investigate Iranian EFL learners' perception and production of politeness in three basic speech acts: request, refusal, and apology. The participants involved 63 MA ELT students. A multiple-choice Discourse Completion Test (DCT) and a politeness rating questionnaire were used to generate participant's data. Selection of situations in DCT was based on three social factors of relative power, social distance, and gender. The emerging data was analyzed mainly based on Blum-Kulka et al.'s Cross-cultural Speech Act Realization Project (CCSARP) and by using descriptive statistics. The data analysis revealed that the participants had enough knowledge about speech act and politeness strategies. In requesting, they mainly relied on indirect strategies; similarly, in refusing, they had a tendency towards using indirect strategies more than direct ones; but in apologizing they acted more directly. Gender as a cultural variable had effect on face saving strategies, and based on Brown \& Levinson's politeness theory, Iranian EFL learners in this study mainly resorted to negative politeness.
\end{abstract}

Index Terms—-politeness strategy, communicative competence, request, refusal, apology, production

\section{INTRODUCTION}

Though the concept of speech acts developed in a purely theoretical atmosphere as a reaction to radical structuralism in linguistics (e.g. see Austin 1962; Searle 1969), it soon became a source of insight for those working in pedagogical realms and motivated an influential wave of research related to pedagogical aspects of this theory. One major goal of such pedagogically-oriented research has been to help the learners develop their competence of speech acts use by providing them with the chance of understanding and using them in a variety of contexts (see, for instance, Olshtain and Blum-Kulka's (1985) study on the perception of English and Hebrew learners' request strategies; House and Kasper's (1987) study on the production of request strategies of advanced learners of L2 English (L1 Danish and German); Tanaka's (1988) study on the requesting strategies of Japanese ESL learners in Australia; Phuong's (2006) study on the refusal speech act of Australian Native Speakers of English and Vietnamese Learners of English; Jalilifar's (2009) investigation of the request strategies of Iranian EFL Learners and Australian native speakers; Istifçi's (2009) study on the apology strategies of intermediate advanced level EFL learners, and native speakers of English; Umale's (2011) study on the refusal strategies of British and Omani learners.

Following this tradition of research in general and to gain a deeper understanding of Iranian English language learners awareness of speech acts conventions in particular, the present research attempted to investigate a group of Iranian participant's awareness of politeness conventions in understanding and producing three speech acts (Request, Refusal and Apology). The study attempted to investigate Iranian ethos in using and understanding different speech acts and also find out the effect of gender as cultural and moderator variable on requesting, apologizing, and refusing strategies. We also studied the types of head acts, supportive discourse moves, on- record, and off- record strategies employed by participants in their speech acts in different contexts. More specifically, the present research addressed the following questions:

1. Do Iranian MA ELT students have enough knowledge of speech acts and politeness strategies?

To answer this question, some other minor questions were addressed:

a) What are the request strategies used by the participants?

b) What are the apology strategies used by the participants?

c) What are the refuse strategies used by the participants? 
2. Which one of one of the five main politeness strategies (based on Brown and Levinson's model) is/are more frequently used by the participants?

3. What is the effect of gender as a cultural variable on the use of requesting, apologizing, and refusing strategies?

\section{REVIEW OF THEORETICAL BACKGROUND}

\section{A. Politeness}

Politeness involves taking account of the feelings of others. A polite person makes others feel comfortable. Brown and Levinson cited in Behm(2008) claim that" every competent speaker of a language, a model person, has face - a public self-image he wants to maintain in communication with other people" (p: 10). Face was used originally by (Goffman, 1967), defined as a mask which changes depending on the audience and the social interaction. Basically, face saving is shown by respecting two basic human needs: the need not to be imposed on (what to avoid) which is called negative face; and the need to be liked and admired which is also called positive face which refers to the desire to be appreciated as a social person (what to do). Brown and Levinson (1987) outline five main types of politeness strategies based on the minimization of loss of face by face-threatening acts (FTA). Their face saving strategies (numbered 1-5) can be observed in the following chart in figure 1.1.

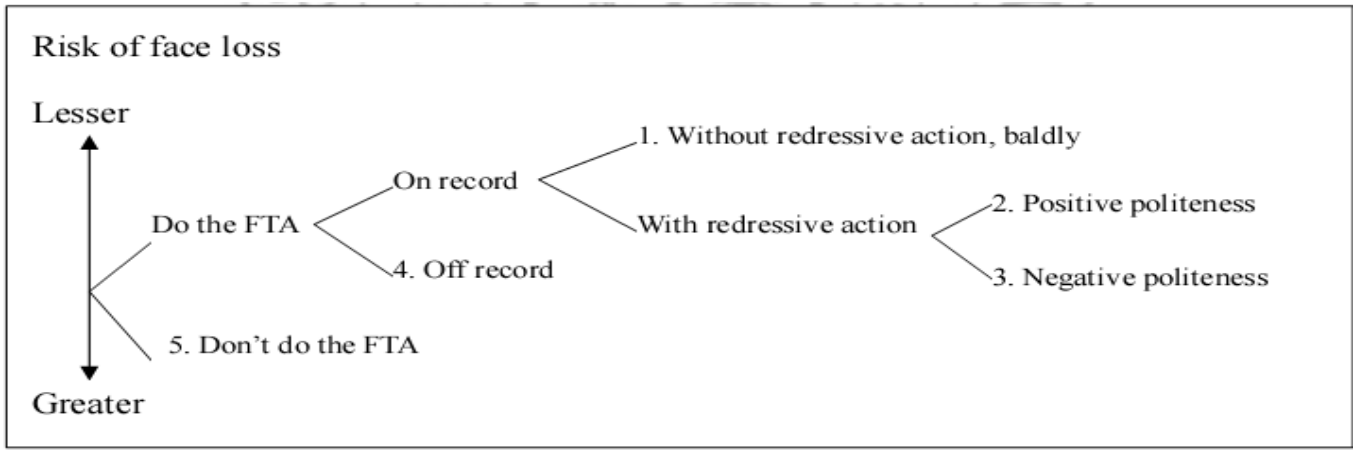

Brown and Levinson 1987: 69

FIGURE 2.8 Possible strategies for doing face-threatening acts

\section{B. Speech Acts Investigated in the Present Research}

Austin (1962) claims that many utterances (things people say) are equivalent to actions. People use language all the time to make things happen. According to speech act theory (Austin 1962; Searle 1969), the performance of a speech act involves the performance of three types of acts: locutionary act (what we say), illocutionary act, (what we mean), and perlocutionary act (how the hearer takes it). Searle (1975) distinguished 'direct' and 'indirect' speech acts. A direct speech act carries the illocutionary force indicating devices (IFID), in which there is a transparent relationship between form and function. However, in an indirect speech act, the illocutionary force of the act is not derivable from the surface structure and it is implicit performative. Of the many types of speech acts included in the proposed taxonomies, here we suffice with defining the ones which have been investigated in the present research and highlighting their role in establishing politeness:

(a) Request has been defined as "attempts on the part of a speaker to get the hearer to perform or to stop performing some kind of action" (Ellis, 1994, p.167). Requests are a good example of speech acts which imply an intrusion on the addressee's territory, thus limiting his/her freedom of action and threatening his/her 'negative face'. In Brown \& Levinson's terms requests are intrinsically FTAs. "Requests can also denote closeness and intimacy since the speaker must feel close enough to the addressee in order to ask him/her to do something and thus requests should also be considered within the realm of positive politeness" (Rosina Reiter, 2000,p.35). Blum-Kulka, House, and Kasper (1989b) cited in Jalilifar (2009) classify requests into three major levels of directness: direct (Mood derivable, Performative, Hedged performative, Obligation statement, Want statements), conventionally indirect (Suggestory formula, Query preparatories) and non-conventionally indirect (Strong hint, and Mild hint).

(b)" Refusal is the speech act of saying no "(Wierzbicka 1987, p. 94). In many cultures, how one says "no" is probably more important than the answer itself. Therefore, sending and receiving a message of "no" is a task that needs special skill. This FTA leads to a tendency on the part of the speakers to make use of certain strategies such as indirectness and polite expressions in order to avoid conflict (Brown and Levinson, 1987). Beebe et al. (1990) cited in Phuong classified refusal strategies as: direct (Performative, Non-performative statement (NO), Non-performative Negative willingness ability), indirect (Statement of regret, Statement of wish, Excuse/reason/explanation, Statement of alternative, Set condition for future or past acceptance, Promise of future acceptance, Statement of principle, Rhetorical question, Threat/statement of negative consequences, Restatement, Unwillingness/insistence, Postponement), and Adjuncts to Refusals ( Statement of positive opinion/feeling or agreement, Statement of empathy, Addressing terms). 
(c) Apology has be defined as regretful acknowledgement of fault or failure. Goffman (1971) views apologies as 'remedial interchanges'; that is to say, remedial work which aims at re-establishing social harmony after a real or virtual offence has been performed. Using Brown \& Levinson's terminology, apologies are generally perceived as negative politeness since they express respect rather than friendliness. Olshtain \& Cohen (1983 as cited in Gonda, 2001) studied apologizing strategies and classified them into Illocutionary force indicating device (taking on responsibility, explanation or account, offer of repair, and promise of forbearance) and Tunçel added categories like questioning or denying, blame, health, exclamation, and request to the list.

\section{METHODS}

\section{A. Participants}

The participants in this study were sixty-three MA students( 39 female \& 24 male) majoring in Teaching English as a Foreign Language at Islamic Azad University of Maraghe, and Tabriz, Iran. In order to choose the participants with a similar level of language proficiency, students who were junior participated in this study. They were chosen according to stratified random sampling. Almost all of the students were between 22 and 31 years of age.

\section{B. Instrument}

The questionnaire developed for this investigation had three parts: Multi-Item Scales, Rating Table, and open-ended Discourse Completion Test (DCT). The important part of this questionnaire was Discourse Completion Test. The (DCT) is a form of questionnaire depicting some natural situations to which the respondents are expected to react and make speech acts as spontaneous as possible ( see appendix).

\section{Procedure}

Before using the questionnaire, it was piloted on a small group (4 male and 4 female participants) in Islamic Azad University of Maraghe. The pilot study proved to be successful. Based on the feedback from the participants and data analysis problems, some minor amendments and modifications were made. After sampling, the questionnaire was distributed to the participants. They were asked to interact like social chat in an actual situation, not think too much, and try to answer the questions as spontaneously as possible.

The data collected through the first part of the questionnaire was analyzed, the responses were either true or false, and for analyzing second part of questionnaire Brown and Levinson's face saving strategies framework was used. All request and apology strategies were analyzed based on Blum-Kulka (1989) CCSARP Coding Manual, and in analyzing refusal strategies, Beebe et al. (1990), and Phuong's (2006) particular coding schemes, and three categories depicting the relative social power - high $(\mathrm{H})$ or equal $(\mathrm{E})$; social distance with two levels: intimate $(\mathrm{I})$ or stranger $(\mathrm{S})$; and gender: Same (S) or Opposite (O) - were used.

\section{RESULTS AND DISCUSSION}

\section{A. A Quantitative Overview}

The results obtained from the first part of the questionnaire are presented in Figure 3.1. It compares the responses of two groups:

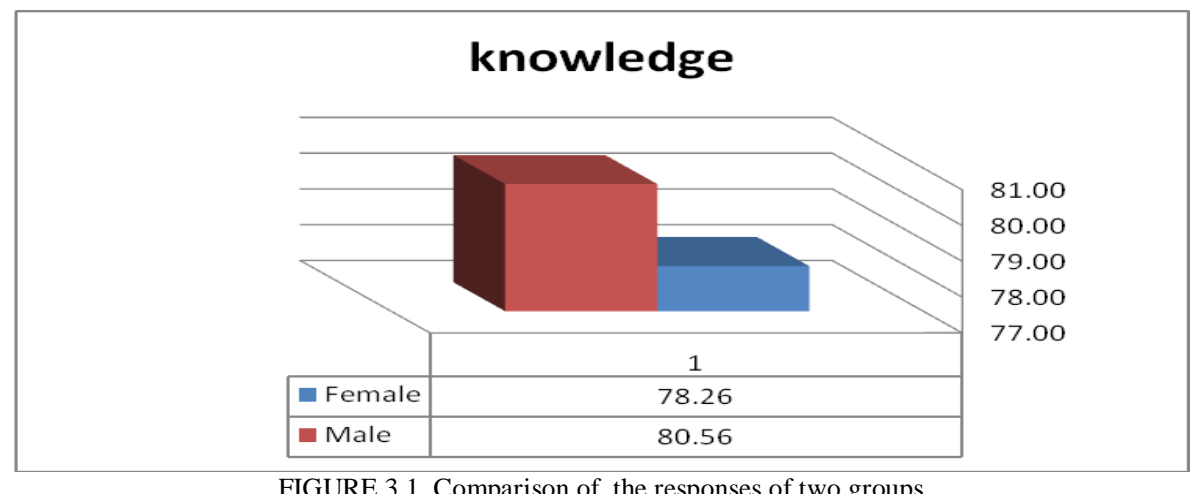

FIGURE 3.1 Comparison of the responses of two groups

The results obtained from the second part of the questionnaire are presented in Table 3.1. It displays the percentage of the participants' responses in each question and situation, and it also compares male and female students' responses. 
TABLE 3.1

MALE AND FEMALE PARTICIPANTS' RATING POLITENESS LEVEL

\begin{tabular}{|c|c|c|c|c|c|c|c|c|c|c|c|}
\hline \multirow{2}{*}{\multicolumn{2}{|c|}{$\begin{array}{l}\text { politeness } \\
\text { rating } \\
\text { table }\end{array}$}} & \multicolumn{2}{|c|}{ Rude } & \multicolumn{2}{|c|}{ impolite } & \multicolumn{2}{|c|}{ average } & \multicolumn{2}{|l|}{ polite } & \multicolumn{2}{|c|}{ very polite } \\
\hline & & \multirow{2}{*}{$\begin{array}{l}\text { Male } \\
\%\end{array}$} & \multirow{2}{*}{\begin{tabular}{|l}
$\begin{array}{l}\text { Female } \\
\%\end{array}$ \\
2.6
\end{tabular}} & \multirow{2}{*}{\begin{tabular}{|l|} 
Male \\
$\%$
\end{tabular}} & \multirow{2}{*}{\begin{tabular}{|l|}
$\begin{array}{l}\text { Female } \\
\%\end{array}$ \\
7.7
\end{tabular}} & \multirow{2}{*}{ 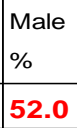 } & \multirow{2}{*}{$\begin{array}{l}\text { Female } \\
\% \\
46.2\end{array}$} & \multirow{2}{*}{$\begin{array}{l}\text { Female } \\
\% \\
20.0\end{array}$} & \multirow{2}{*}{$\begin{array}{l}\text { Male } \\
\% \\
30.8\end{array}$} & \multirow{2}{*}{$\begin{array}{l}\text { Female } \\
\%\end{array}$} & \multirow{2}{*}{\begin{tabular}{|l|}
$\begin{array}{l}\text { Male } \\
\%\end{array}$ \\
12.8
\end{tabular}} \\
\hline \multirow{5}{*}{ 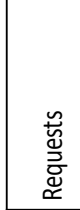 } & 1 & & & & & & & & & & \\
\hline & 2 & 0.0 & 2.6 & 4.0 & 0.0 & 16.0 & 7.7 & 40.0 & 69.2 & 20.0 & 23.1 \\
\hline & 3 & 20.0 & 15.4 & 20.0 & 25.6 & 16.0 & 30.8 & 24.0 & 17.9 & 16.0 & 5.1 \\
\hline & 4 & 72.0 & 38.5 & 36.0 & 43.6 & 36.0 & 5.1 & 4.0 & 2.6 & 4.0 & 0.0 \\
\hline & 5 & 0.0 & 2.6 & 16.0 & 7.7 & 76.0 & 43.6 & 0.0 & 25.6 & 0.0 & 23.1 \\
\hline \multirow{5}{*}{ 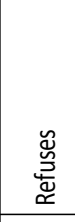 } & 6 & 0.0 & 2.6 & 0.0 & 2.6 & 12.0 & 12.8 & 36.0 & 28.2 & 44.0 & 51.3 \\
\hline & 7 & 40.0 & 12.8 & 36.0 & 30.8 & 20.0 & 33.3 & 12.0 & 17.9 & 0.0 & 0.0 \\
\hline & 8 & 36.0 & 30.8 & 36.0 & 43.6 & 24.0 & 28.2 & 8.0 & 2.6 & 0.0 & 0.0 \\
\hline & 9 & 40.0 & 51.3 & 24.0 & 33.3 & 24.0 & 15.4 & 0.0 & 0.0 & 0.0 & 0.0 \\
\hline & 10 & 40.0 & 12.8 & 4.0 & 5.1 & 24.0 & 59.0 & 16.0 & 12.8 & 4.0 & 7.7 \\
\hline \multirow{5}{*}{$\begin{array}{l}\frac{\mathscr{O}}{20} \\
\frac{0}{0} \\
\frac{0}{1}\end{array}$} & 11 & 0.0 & 2.6 & 0.0 & 0.0 & 4.0 & 10.3 & 36.0 & 53.8 & 60.0 & 33.3 \\
\hline & 12 & 24.0 & 28.2 & 32.0 & 41.0 & 20.0 & 23.1 & 16.0 & 7.7 & 0.0 & 0.0 \\
\hline & 13 & 0.0 & 0.0 & 4.0 & 0.0 & 8.0 & 5.1 & 16.0 & 30.8 & 72.0 & 64.1 \\
\hline & 14 & 24.0 & 33.3 & 40.0 & 56.4 & 32.0 & 10.3 & 4.0 & 0.0 & 4.0 & 0.0 \\
\hline & 15 & 40.0 & 20.5 & 20.0 & 28.2 & 16.0 & 46.2 & 16.0 & 5.1 & 8.0 & 0.0 \\
\hline
\end{tabular}

Figure 3.2 displays the comparison of requesting head act strategies used by male and female participants. It shows that male and female students used nearly the same strategies in their responses.

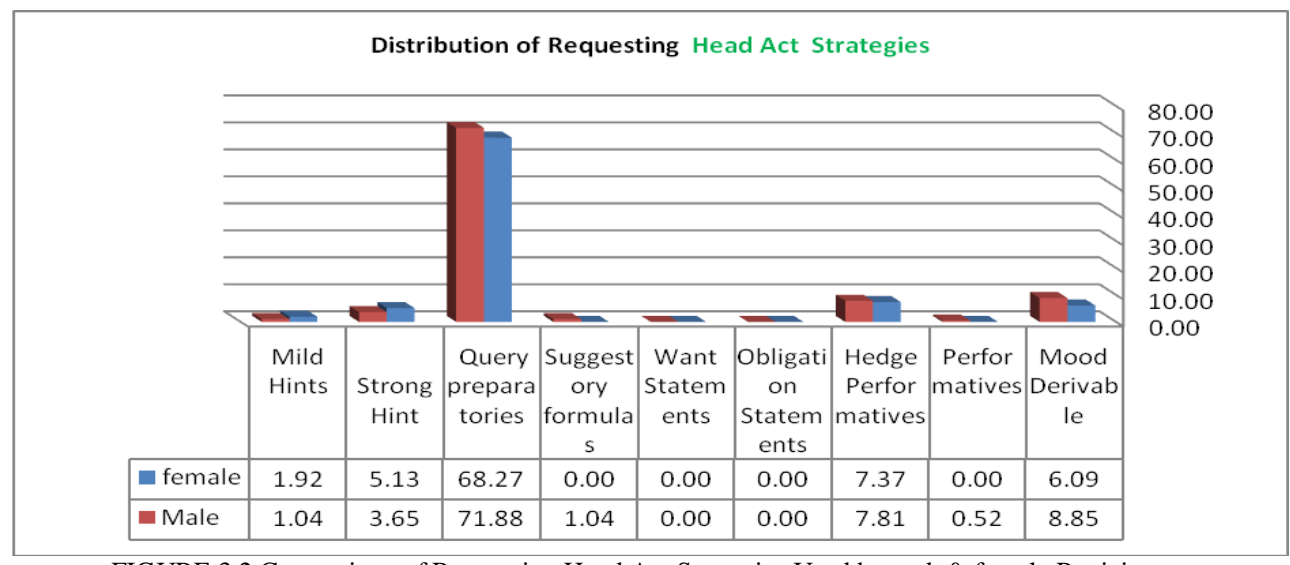

FIGURE 3.2 Comparison of Requesting Head Act Strategies Used by male\& female Participants

Generally speaking, the participants in this study have preferred to use conventional indirect strategies $(70.04 \%)$. The second most frequently used strategy observed in the participants' data is direct strategy (14.88\%), and the 1 least frequently used strategy was non-conventional indirect strategy (6.15\%) (see Figure 3.3).

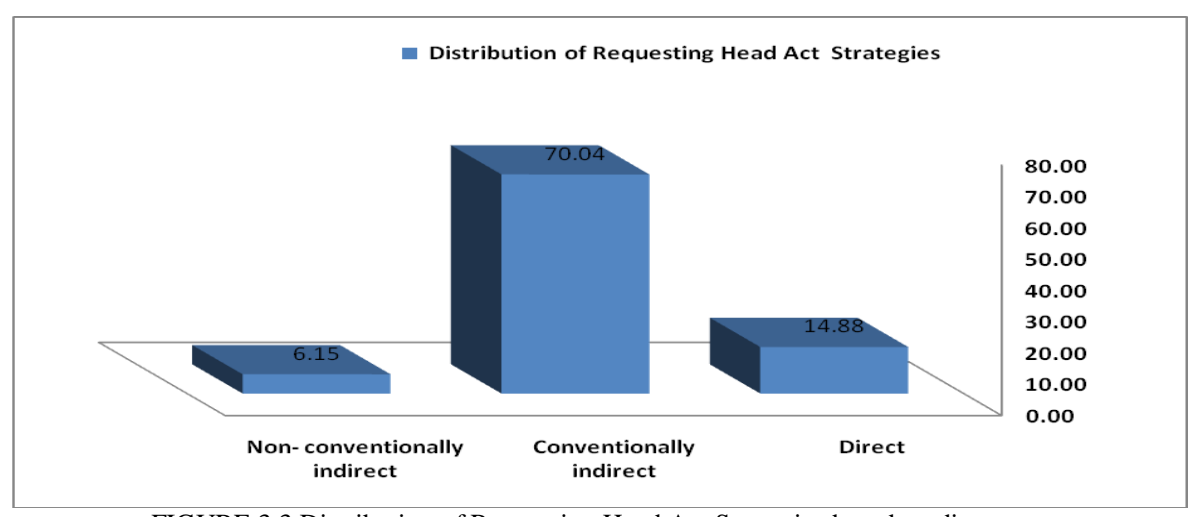

FIGURE 3.3 Distribution of Requesting Head Act Strategies based on directness 
Figure 3.4 compares requesting Mitigating Supportive Moves used by male and female Participants. The Grounder strategy $(9.92 \%)$ was found to be the most frequently used Mitigating Supportive Moves strategy.

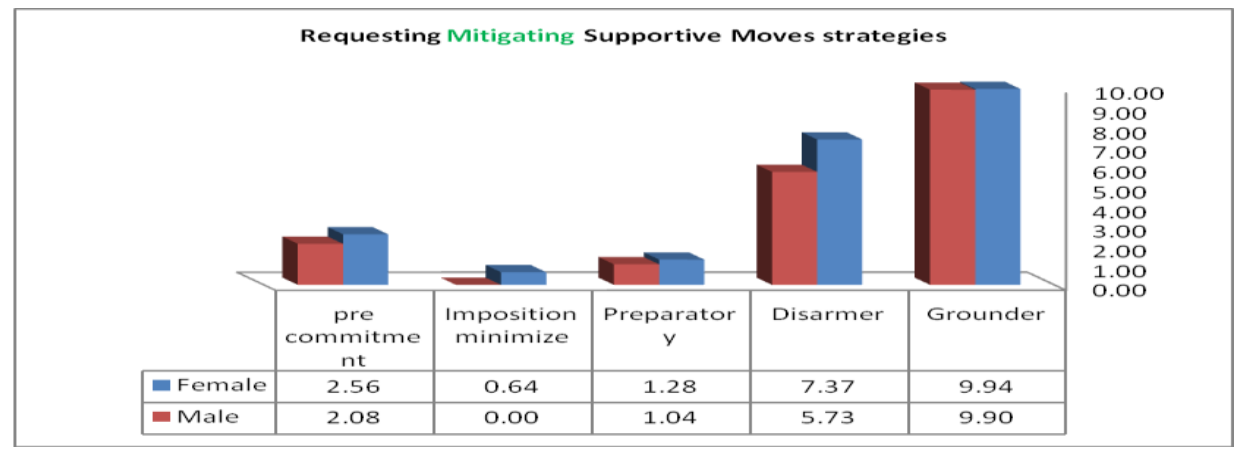

FIGURE 3.4 Comparison of Requesting Mitigating Supportive Moves Used by Participants

Figure 3.5 shows that the differences between two groups are not significant. Only it was in situation IIIA that female participants had a different performance (16.3\% for females vs. 5.21 for males). Generally speaking, the participants in this study have preferred to use indirect strategies like Excuse/Reason/Explanation (IIC) and Statement of regret (IIA) more frequently $(74.40 \%$ and $69.05 \%)$.

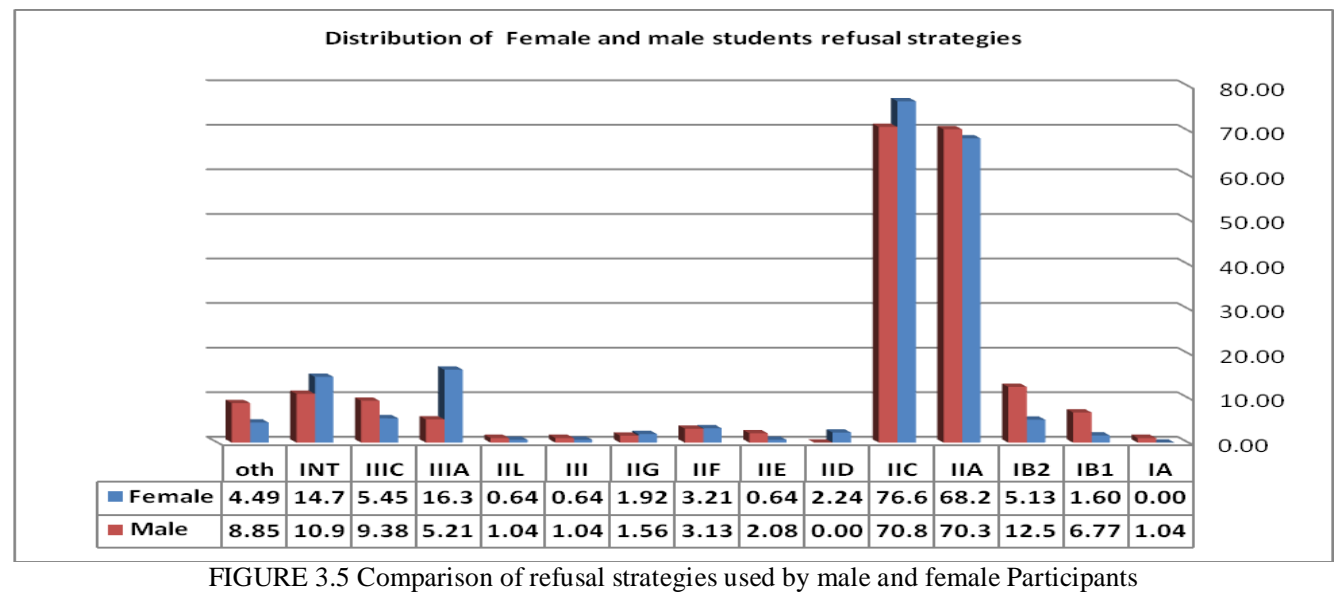

According to Figure 3.6, most of the participants in this study preferred to apologize directly by using Illocutionary force indicating devices (IFIDS) strategy $(78.57 \%$.). The second most frequently used apologizing strategy by the participants was exclamation \& intensifying $(46.03 \%)$.

The third frequent strategy was acknowledging responsibility for the offense (RESP) $(22.82 \%$.). The next most frequently used apologizing strategy by participants $(20.44 \%)$ was offer of repair/redress (REPR) that is employed when the speaker compensates the addressee for any damage resulting from his/her infraction. $5.36 \%$ of the choices was devoted to Explanation of an account (EXPL) through which the speakers give an account of the reasons which brought about the offence. For more information about the preference of apologizing strategies see Figure 3.6.

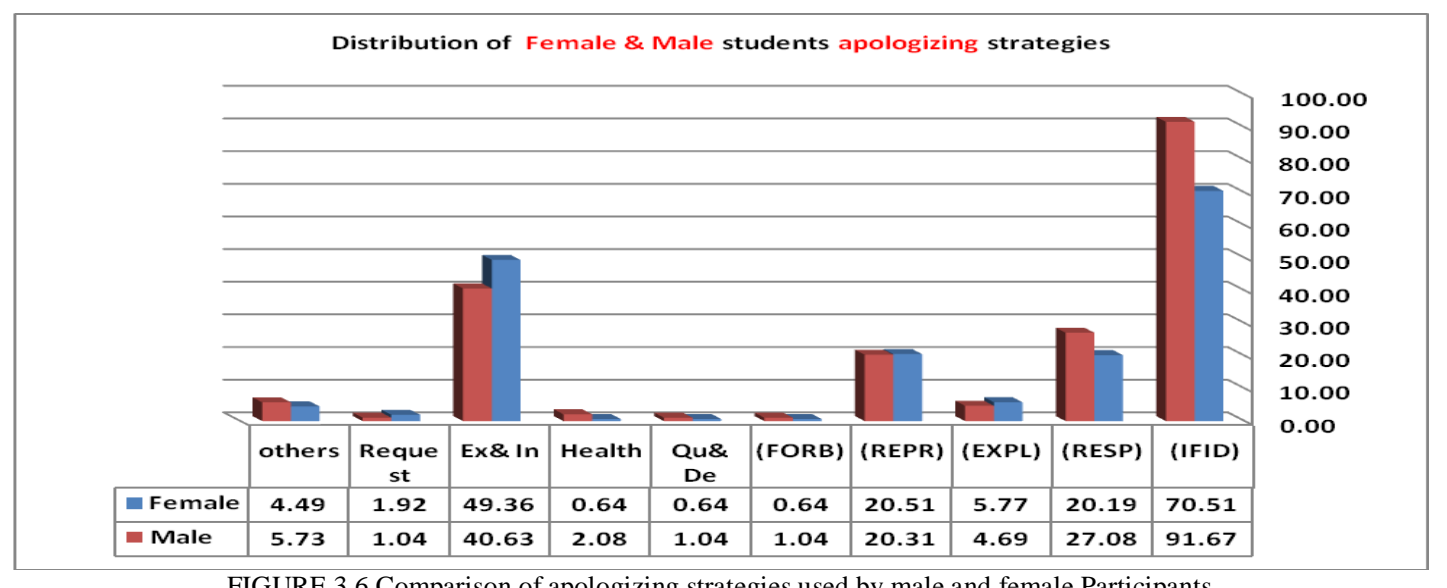

FIGURE 3.6 Comparison of apologizing strategies used by male and female Participants 


\section{B. Evaluation of the Research Questions}

\section{Research question 1: Do Iranian MA ELT students have enough knowledge of speech acts and politeness strategies?}

The results obtained from the first part of the questionnaire makes clear that the participants had enough cognitive knowledge about politeness; however, regarding the findings of their politeness rating, it appears that most of the subjects didn't have enough communicative and pragmatic competence to rate them appropriately. But the results of the analysis of requesting, refusing, and apologizing speech acts showed that Iranian MA ELT students had enough knowledge as most of them preferred to use indirectness strategies with softeners and mitigating supportive moves in requesting and refusing, and directness with intensifying and mitigating in apologizing. Therefore, a tentative interpretation might be that Iranian MA ELT students have enough knowledge of speech acts and politeness strategies.

Research question 1a: What are the request strategies used by the participants?

According to Figure 3.2, the most commonly used head act strategy by the respondents is the query preparatory head act strategy $(69.64 \%)$. This strategy is a conventional indirect requesting head act strategy. It was the strategy frequently chosen by both groups as a requesting strategy in almost all situations. In fact, both groups employ conventional indirectness (70.04 \%) (see Figure 3.3). These results are in line with the CCSARP project of Blum-Kulka et al. (1989) .Other studies such as that conducted by Umar (2004), and Jalilifar (2009) have also shown higher tendency among their subjects to use conventional indirectness over other requestive strategies.

The results of the study also revealed that Grounder strategy corresponding to a percentage of $9.92 \%$ was found to be the most frequent Mitigating Supportive Moves strategies used by the participants (9.92\%). Figure 3.4 shows the respondents' preference to gives reasons, explanations, or justifications for their request in most situations to minimize the negative effect of their request. This finding is in line with the findings of Balci (2009).

From Brown \& Levinson's (1987) Politeness Theory perspective, the participants in this study were found to have a tendency to use negative politeness strategies more frequently. Since requesting is a face threatening act, one explanation might be that participants used Query preparatory as a conventional indirectness, Grounder, and Please as mitigating supportive moves to minimize the negative effect of their request on the hearer.

\section{Research question $1 b$ : What are the apology strategies used by the participants?}

As Figure 3.4 shows, Illocutionary force indicating device (IFID) is the most frequently used apology strategy by both groups (78.57 \%). This finding is in line with Olshtain and Cohen( 1983), Blum-Kulka and Olshtain(1984), and Balci's (2009).

From using Intensifying point of view, this study is in line with Reiter (2000). From IFID \& RESP point of view, this study is also in line with Afghari \& Kaviani (2005); moreover, considering the use of EXPL\& REPR, there is a little difference between the findings of this study and Afghari \& Kaviani's.

\section{Research question 1c: What are the refusal strategies used by the participants?}

A major finding of the refusal part of the study is that the respondents in this study have mainly preferred to use Excuse/Reason /Explanation (IIC) $(74.40 \%)$. This strategy is within the framework of indirect refusal strategy. This finding is in line with Hiba, et al. (2010), and Phuong (2006). Statement of regret (IIA) (69.05\%) was the second frequently used strategy by the subjects .Again, this finding is in line with Phuong (2006). However, it is not in line with Hiba ,et al. (2010). The subjects used these two strategies with the frequency of $71.73 \%$ that is more than the average of the thirteen other strategies (see Figure 3.5). Preferring to use these kinds of strategies clearly indicates that the participants in this study tended to use indirect strategies more than direct ones that is in line with Chen (1996), Hiba, et al. (2010), and Phuong (2006).

Since refusing indirectly is considered a face saving strategy, it can be inferred that the participants in this study have enough perception about appropriateness and politeness strategies.

Research question 2: Do the participants have a tendency towards one of the five main politeness strategies (based on Brown and Levinson's model)?

One of the major findings of this study is that the respondents have preferred to use indirectness with requesting and refusal strategizes, and directness with apologizing. Looking at the issue from the perspective of Brown \& Levinson's (1987) Politeness Theory, participants in this study regarded interlocutor's negative face; therefore, they preferred to use negative politeness strategies. A tentative interpretation might be that Iranian MA ELT students have tendency towards using negative politeness strategies.

Research question 3: what is the effect of gender as a cultural variable on requesting, apologizing, and refusing strategies?

Comparison of the means of two groups in the first part of the questionnaire showed that male respondents outperformed the female respondents. Therefore, it appears that male participants' politeness cognitive knowledge was a little bit better than female participants;

By comparing female and male participants' politeness rating table, it was found that there were some significant differences between these two groups. One of the major differences was that male participants considered imperative requesting rude when they were asking their roommate to "open the window "(see Table 3.1). Female participants in politeness rating part of this study had a tendency towards using positive politeness. This might mean that they consider directness as an appropriate strategy when their interlocutor is a close friend. 
There was another major difference in understanding the utterances like" It is too hot here". According to Brown \& Levinson (1987), this kind of requesting is an off record strategy, and it is one of the very polite ways to save partners' face when the risk of loss of 'face' is great. Male respondents rated this requesting as polite or very polite but the females rated it as an average strategy when they wanted their roommate to open the window. One possible conclusion can be that requesting indirectly (using off record strategy) from close friends can be face threatening for female participants.

According to Brown \& Levinson (1987) utterances like "Let's cancel the class" is in the framework of positive politeness strategy and according to R. Ellis (1994) positive strategy occurs when there is minimal social distance and little power difference between the participants. Male respondents considered the mentioned strategy ruder than females when they were refusing their professor's request. Another major refusal difference between these two groups was in understanding the sentence "saying nothing, but look at sadly". Most of the males considered this strategy rude while female rated it as an average strategy.

The results of the analyzing of apologizing rating table showed that in rating the utterance "Say nothing, but enter the class and look at regretfully" male and female participants performed differently. Most of the males considered this strategy rude while females rated it as an average strategy when they owe their professor an apology. According to Brown \& Levinson (1987), this strategy includes cases in which nothing is said due to the fact that the risk involved is too great. The male participants again rated these kinds of strategies ruder than did the females. This might be related to gender differences or using body language that had effect on male (see Table 3.1).

According to Figure 3.2, there were no major differences between these two groups regarding their overall requesting strategies. However, male participants used Query preparatories, suggestory formula, hedged performative, performative, and mood derivable head act strategies more frequently than did females. In contrast, the females used strong hint and mild hint more frequently than did the males. A tentative interpretation might be that females have a stronger tendency towards using Non-conventionally indirect strategy. To use Brown \& Levinson's (1987) politeness terminology, it is an off record strategy by which speakers use indirect language and remove the potential imposing on the hearer.

Figure 3.3 compares the Requesting Mitigating Supportive Moves used by both groups. It clearly shows that male respondents' performance closely corresponds with the performance of female participants. But, females preferred to use all of the mitigating supportive moves more than males did. It is likely due to the gender differences: female participants appear to be more sensitive than males in saving addressee's face.

Figure 3.5 compares the refusal Strategies used by male and female participants. The differences were in the use of following strategies (male participants used them more frequently than did females): Performative (IA), "No" as a nonperformative statement (IB1), Negative willingness ability as another Non-performative statement (IB2), Statement of regret (IIA), Set condition for future or past acceptance (IIE), Threat/statement of negative consequences (III), Postponement (IIL), and Addressing terms (IIIC). On the other hand, females preferred to use the following strategies more than males: Statement of positive opinion/feeling or agreement (IIIA), Excuse/reason/explanation (IIC), Promise of future acceptance (IIF), Statement of principle (IIG), Statement of alternative (IID), and Intensifying (INT) .According to Figure 3.5, since male respondents preferred to use direct strategies (IA, IB1, ,And B2) more frequently than did females (IIIA, IIC, IIF, IIG, IID), one possible explanation is that female participants have a stronger tendency towards using indirect strategies.

Figure 3.6, demonstrates the differences and similarities between male \& females' apologizing strategies. It shows that male subjects used Illocutionary Force Indicating Device (IFID), Taking on Responsibility, Promise of Forbearance, Health, and questioning more frequently than did female participants. However, females preferred to use Explanation, Offer of Repair/Restitution, Exclamation (EXL!), intensifying, and Request more frequently than did the male respondents. According to Figure 3.6, male respondents preferred to use direct strategies about $20 \%$ more than females did; therefore, a tentative interpretation might be that male participants apologize more directly than females.

Generally speaking the findings of this study show that gender as a cultural variable had effect on requesting, apologizing, and refusing strategies.

\section{APPENDIX DisCOURSE COMPLETION TEST}

Participants Discourse Completion Test (DCT)

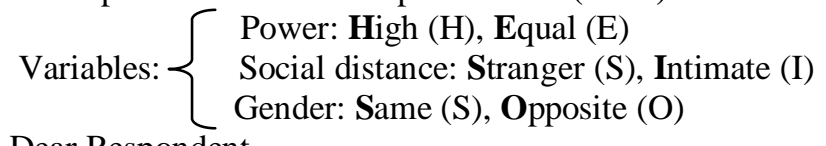

Dear Respondent,

The researcher is conducting a study entitled A Study of Iranian EFL learner's perception and production of

Politeness in request, refusal, and apology. You are kindly requested to answer the items of this questionnaire carefully, realistically, honestly and accurately. Rest assured that the information obtained in the course of this study will be kept confidential and used only for the purposes of academic research.

Thank you

Part (1): please choose the best option. 
1- An utterance that serves as a function in communication is
a) speech act
b) face
c) Politeness
d) semantics

2-The study of what people mean by language when they use it in the normal context of social life is ...
a) speech act
b) face
c) Politeness
d) pragmatics

3-The desire to see one's action unimpeded by others and the need to have freedom from imposition refers to
a) speech act
b) negative face
c) Politeness
d) Positive face

4-The desire to be appreciated as a social person, and It is the need to be connected, to belong and to be a member of the group refers to...
a) speech act
b) negative face
c) Politeness
d) Positive face

5-preserving or intended to preserve one's dignity, self-respect, or good reputation is....
a) face threatening
b) negative face
c) face saving
d) Positive face

6-The study of language in relation to social factors is

a) sociolinguistics b) sociology of language c) applied linguistics d) linguistics applied

Part (2): please circle numbers to rate the politeness level of the following statements from 0 (rude) to 5(very polite), according to the written speech act.

\begin{tabular}{|c|c|c|c|c|c|c|}
\hline$\Rightarrow$ & Asking your roommate to open the window: & \multicolumn{5}{|c|}{ Rude-Impolite-Average-Polite-very polite } \\
\hline \multirow{5}{*}{ 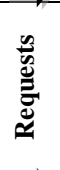 } & 1- All of us have the same problem, so let's open the window. & 1 & 2 & 3 & 4 & 5 \\
\hline & 2- I know you are busy, but could you open the window? & 1 & 2 & 3 & 4 & 5 \\
\hline & 3- Say nothing, but move a piece of paper to show it is too hot. & 1 & 2 & 3 & 4 & 5 \\
\hline & 4-Open the window. & 1 & 2 & 3 & 4 & 5 \\
\hline & 5 - It is too hot here. & 1 & 2 & 3 & 4 & 5 \\
\hline$\Rightarrow$ & Refusing your professor's request: & \multicolumn{5}{|c|}{ Rude-Impolite-Average-Polite -very polite } \\
\hline \multirow{5}{*}{ 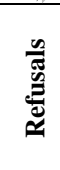 } & 1- I know you want to help us, but would you mind canceling that class? & 1 & 2 & 3 & 4 & 5 \\
\hline & 2-Let's cancel the class. & 1 & 2 & 3 & 4 & 5 \\
\hline & 3- I can't come to the class that day. & 1 & 2 & 3 & 4 & 5 \\
\hline & 4- Finishing the book isn't necessary. & 1 & 2 & 3 & 4 & 5 \\
\hline & 5- Say nothing, but look at sadly. & 1 & 2 & 3 & 4 & 5 \\
\hline$\Rightarrow$ & When you owe your professor an apology: & \multicolumn{5}{|c|}{ Rude-Impolite-Average-Polite -very polite } \\
\hline \multirow{5}{*}{ 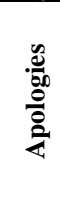 } & 1- I apologize for not being able to attend the class on time. & 1 & 2 & 3 & 4 & 5 \\
\hline & 2- Sorry, but you shouldn't be so sensitive. I am person like you. & 1 & 2 & 3 & 4 & 5 \\
\hline & $\begin{array}{l}\text { 3- I'm very sorry Professor, I'm late. Could you please give me an opportunity } \\
\text { to see you now? }\end{array}$ & 1 & 2 & 3 & 4 & 5 \\
\hline & 4- The bus was late, It's not my fault. & 1 & 2 & 3 & 4 & 5 \\
\hline & 5- Say nothing, but enter the class and look at regretfully. & 1 & 2 & 3 & 4 & 5 \\
\hline
\end{tabular}

Part (3): Please read the following descriptions of situations and write what you will say in each situation. If your answer in part B is the same as part A, please mark only the same. If it is not, write differently.

\section{Request Strategies}

1. A- (HSS): You have to prepare homework. You need a book. That particular book has been seen by your friend in the office of a professor whom you don't know. You want to borrow his expensive book for a few days. How will you request?

B- (HSO): how will you request if that professor has opposite gender? The same

2. A- (HIS): You are writing exam .One of your professors whom you are very close with is speaking with his coworker very loudly. You decide to ask him not to speak loudly. What will you say? ................................................................................

B- (HIO): how will you request if your professor has opposite gender? The same

3. A- (ESS): you and your classmate would like to take a photo together to remember this happy moment. You decide to ask a nearby male student who is stranger to you, to do this favor. What will you say?.

B- (ESO): how will you request if the student has opposite gender? The same

4. A- (EIS): You have an exam next week. You have lost your book, and you know that your best friend has that book. You are going to ask for his book to photocopy. How will you

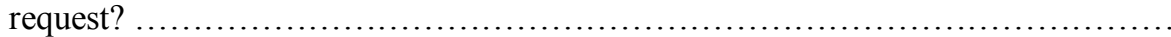

B- (EIO): how will you request if that person has opposite gender? The same 
1. A- (HSS): You are a student at a high school. One of the new comer teachers whom you don't know and isn't your teacher wants to use your dictionary. He /she asks if he/she can borrow your dictionary for a while. He says "I left my dictionary at home. Could you please lend me yours for a few minutes?" You refuse his request by saying:

B- (HSO): How will you refuse if the teacher has opposite gender? The same

2. A-(HIS): You are an assistant to a Professor. At the end of the office hours, you are going to leave. The Professor

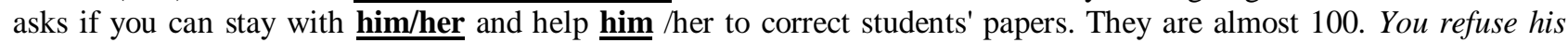
request by saying:

B. (HIOHR): How will you refuse if the professor has opposite gender? The same

3. A-(ESS): You are a student at a University. You are about to go home in your car. A student, Prou you do not know before, approaches and asks you for a lift home, He says "I and you live in the same area of the city". You refuse his request by saying:.

B. (ESOHR): How will you refuse if the student has opposite gender? The same

4. A-(EIS): A close friend of yours asks if he/she can borrow your notes as he could not come to the lecture last week. He says "Oh no, we have an exam tomorrow, but I don't have the notes from last week. Could I borrow yours?" You refuse his request by saying:

B- (EIO): What will you say if that person has opposite gender? The same

\section{Apologies}

1. A-(HSS): Backing out of a parking place, you run into the side of another car. It was clearly your fault. You dent its door. The driver whom you don't know gets out and comes over to you angrily. The driver is an adult, but you are young. Driver: "Can't you look where you're going? See what you've done!"You:

B- (HSO): How will you apologize if the driver has opposite gender? The same

2. A- (HIS): At a cafeteria: You are carrying your meal to your table. When you are walking between tables, you stumble and your soup spills over your uncle' shirt. How will you apologize? You:

B- (HIO): How will you apologize if your soup spills over your aunt's blouse? The same

3-A-(ESS): Rushing to get to class on time, you run round the corner and bump into a student who was waiting there and whom you don't know at all, almost knocking that person down. How will you

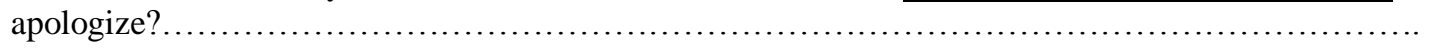

B- (ESO): How will you apologize if the student has opposite gender? The same

4. A-(EIS): Spending an evening at a close friend's apartment, you accidentally break an old expensive vase belonging to close friend. How will you apologize?.

B. (EIO): How will you apologize if that person has opposite gender? The same

\section{General Information:}

Gender: $\square$ Male $\square$ Female

Name:.....

Age:

Thanks a lot for your time and help

\author{
Hometown: \\ Semester: \\ University name:
}

\section{REFERENCES}

[1] Afghari, A., \&. Kaviani, V .(2005). Apology speech act realization patterns in Persian. Iranian Journal of Applied Linguistics (IJAL), 8(2), 19-20.

[2] Balci, B. (2009). A comparative study on the performance of requests and apologies by Turkish and American teenagers: a pragmatic competence point of view. Unpublished master's thesis, University of Cukurova, Adana, Turkey.

[3] Barron, A. (2001). Acquisition in interlanguage pragmatics: learning how to do thing with words in a study abroad context., Amsterdam, Netherlands: John Benjamins Publishing Company.

[4] Behm, J. (2008). A contrastive analysis of politeness: Requests and refusals in German and English. Retrieved October 25, 2011, from: www.books.google.com

[5] Blum-Kulka, S., \& Olshtain, E.(1984). Requests and apologies: A cross-cultural study of speech act realization patterns (CCSARP). Applied Linguistics, 5(3), 196-214. 
[6] Brown, P., \& Levinson, S. (1987). Politeness: Some universals in language usage. New York: Cambridge University Press.

[7] Callies, M. (2009). Information highlighting in advanced learner English. The Syntax-Pragmatics Interface in Second Language Acquisition. Amsterdam, Netherlands: John Benjamins Publishing Company.

[8] Chomsky, N. (1965). Aspects of the Theory of Syntax, Cambridge, Mass: MIT Press

[9] Crystal, D. (2003). A Dictionary of Linguistics \&Phonetics; (5th ed).Oxford: Blackwell.

[10] Ellis, R. (1994). The studies of second language acquisition. Oxford: Oxford University Press.

[11] Eryani, A. A. (2007). Refusal strategies by Yemeni EFL learners. The Asian EFL Journal, 9(2), 83-101.

[12] Goffman, E. (1967). Interaction ritual: Essays on face-to-face behavior. New York: Anchor Books.

[13] Gonda, T. (2001). The speech act of apology: apology behaviour of British English and advanced Greek speakers of English. Unpublished master's thesis, University of Essex.

[14] Hiba, Q.A. S., Salasiah, C. L., \& Raja, R. R. S. (2010). A study on strategies used in Iraqi Arabic to refuse suggestions. The International Journal of Language Society and Culture, 30, 86. Retrieved from http://www.educ.utas.edu.au/users/tle/journal/(accessed 8/7/2012)

[15] Hymes, D. (1972). On Communicative Competence in j. B pride and J. Holes (Eds) sociolinguistics (pp. 269293).Harmondsworth: penguin.

[16] Istifçi, I. (2009). The use of apologies by EFL learners. English Language Teaching, 2(3), 16. Retrieved from http://www.ccsenet.org/journal/ (accessed 8/7/2012).

[17] Jalilifar, A. (2009). Request strategies: cross-sectional study of Iranian EFL learners and Australian native speakers. English Language Teaching, 2(1), 47. Retrieved from http://www.ccsenet.org/journal/ (accessed 8/7/2012).

[18] Kasper, G. (1997). Can pragmatic competence be taught? Retrieved November 16, 2011 from http://www.nflrc.hawaii.edu/NetWorks/NW06/

[19] Kenji, K. (1990). A study of Japanese and American perceptions of politeness in requests. Washington: ERIC Clearinghouse.

[20] McKay, S., Nancy, H. H. (1996). Sociolingüistics and language teaching. Cambridge University Press, New York, NY 100114211,USA.

[21] Moore, A. (2001).Pragmatics and speech acts. Retrieved from www.shunsley.eril.net/armoore

[22] Phuong, N.T.M.(2006). Cross-cultural pragmatics: refusals of requests by Australian native speakers of English and Vietnamese learners of English. Unpublished master's thesis University Of Queens, New York City, USA.

[23] Reiter, R. (2000). Linguistic politeness in Britain and Uruguay; A contrastive study of requests and apologies. Amsterdam, The Netherlands: John Benjamins Publishing Company.

[24] Umale, J. (2011). Pragmatic failure in refusal strategies: British versus Omani interlocutors. Arab World English Journal, $2(1), 18-46$.

[25] Umar, A. M. A. (2004). Request strategies as used by advanced Arab. English as a Foreign Language. Umm Al-Qura University Journal of Educational \& Social Sciences \& Humanities, 16(1),41-87.

[26] Widdowson, H. G. (1978). Teaching Language as Communication,. London: Oxford University Press.

[27] Widdowson, H.G. (1996). Linguistics .London: Oxford University Press.

[28] Wierzbicka. (1987). English speech act verbs: a semantic dictionary. Retrieved January 10, 2011, from: www.books.google.com

[29] Yule, G. (1996) . Pragmatics. Oxford: Oxford University Press.

Davud Kuhi is a PhD in applied linguistics. He is currently a faculty member of Islamic Azad University, Maragheh Branch. He has been teaching English for over 10 years for B.A and M.A students in TEFL. His main areas of interest are genre analysis and discourse analysis.

Mohammad Jadidi is an M.A in TEFL. He has experience of teaching in high school as well as Goftman Language Institution. $\mathrm{He}$ is the head of Goftman Language Institute in Ajabshir, East Azarbaijan He holds an M.A from Islamic Azad University, Maragheh Branch. His main areas of interest are discourse analysis, politeness, and teaching methodology. 